\title{
Plaučių vèžys ir alternatyvus gydymas: ar dera tarpusavyje
}

\author{
Rūta Nutautienè \\ Respublikinè Kauno ligoninè
}

Plaučių vėžys yra antra pagal dažnumą onkologinė liga (po krūties vèžio) Jungtinėje Karalystėje [1]. Plaučių vėžiu dažniau serga vyrai. Kad ir kaip liūdna, vis daugèja ir plaučiu vėžiu sergančiu moteru [1]. Vyrams tai dažniausia onkologinė liga po prostatos vež̌io, moterims - antra po krūties vėžio. Beveik 9 iš 10 atvejų plaučiu vėžys diagnozuojamas vyresniems kaip 60 metų asmenims [1]. Lietuvos vyrų pagal amžių standartizuoti $2008 \mathrm{~m}$. rodikliai yra prastesni negu Europos Sajungos vidurkis: sergamumas 55,6 atv. 100 tūkst. gyv. (registruoti 1265 nauji atvejai), mirtingumas - 49,8 atv. 100 tūkst. gyv. (1156 mirtys). Tačiau geresni moterų rodikliai (sergamumas $-6,5$ atv. 100 tūkst. gyv., mirtingumas - 5,7 atv. 100 tūkst. gyv.) atsvẻre ir bendruosius mūsų šalies rodiklius (atitinkamai 25,9 atv. ir 22,8 atv. 100 tūkst. gyv.) [2].

Kokios plaučių véžio priežastys? Jụ yra daugybè ir tikriausiai dar ne visos žinomos, kaip ir pačios plaučiu vėžio ligos. Bet dèl svarbiausios priežasties nedvejojama - tai rūkymas (tiek aktyvus, tiek pasyvus!). Be abejo, reikšmès turi ir profesiniai veiksniai, oro tarša, neprofesinès jonizuojančios spinduliuotès ekspozicijos poveikis ir t.t. Farmacijos pramoné juda ì prieki - sukurta daugybé ịvairiu farmakologiniu grupių vaistinių preparatų vèžiui gydyti (chemoterapija, biologinè terapija ir pan.). Priklausomai nuo stadijos ir molekulinių genetinių žymenų, gali būti taikomas spindulinis, chemospindulinis, operacinis gydymas, taikiniu terapija, o kartais tik simptominis gydymas. Vis dèlto plaučiụ vėžys išlieka viena agresyvesnių onkologinių ligu, kuria sergant gyvenimo trukmè gana trumpa. Bene svarbiausia, ką galima padaryti - stengtis išvengti šios ligos. Žinant, kad pagrindinis ligos rizikos veiksnys yra rūkymas, profilaktikos tikslu derètu jo atsisakyti. Svarbu, atsiradus naujiems kvèpavimo sistemos simptomams ar bendriems negalavimams be aiškios priežasties, laiku ittarti šią klastingą ligą, nes tik pradinèse stadijose galima tikètis geresniu gydymo rezultatų. Neretai véžiu susirgę asmenys ar jų artimieji (ypač po sekinančio onkologinès ligos gydymo etapo), be plaučiu véžio rekomendacijomis pagristo gydymo, ieško ir papildomo - svarbiausia tokio, kuris stiprintų imuninę sistemą, o kartu ir visą organizmą, tikèdami, kad jis palengvins kovą su klastinga liga.

\section{KLINIKINIAI SIMPTOMAI}

Nèra nẻ vieno simptomo, kuris būtu būdingas tik plaučių vėžiui. Nėra ir apibrèžto laiko, kada žmogus pajunta pirmuosius negalavimus susirgęs šia liga. Tai labai priklauso nuo kiekvieno organizmo (bendrosios sveikatos būklès, gretutiniu ligu ir pan.), taip pat nuo naviko dydžio, jo išplitimo. Pats "nekalčiausias" plaučiu vėžio simptomas prasidèjęs ar pastiprèjęs kosulys (su skrepliavimu ar be jo). Jis nesukelia ženklesnio diskomforto: kadangi dažniausiai plaučių vėžiu serga rūkantys asmenys ir kosulys gali būti dažnas jų palydovas, $\mathfrak{i}$ jo pastiprèjimą tiesiog neatkreipiama dèmesio. Kita problema, kad užsitęsęs kosulys gali imituoti ir peršalimą, dèl kurio vèlgi retas kreipiasi pagalbos ị specialistą. Galbūt labiau ieškoti pagalbos priverčia atsiradęs dusulys ar krūtinès skausmas - dar vieni iš dažnesnių plaučiu vėžio simptomų. Na ir galiausiai, suskumbama ieškoti priežasties, kai pradeda kristi svoris, sutrinka apetitas, dingsta jègos atlikti kasdienius darbus, rūpintis buitimi. Kraujo atkosèjimas gali būti pirmas, o kartu ir paskutinis plaučių vèžio simptomas. Aprašyti dažniausiai pasitaikantys plaučiu onkologinès ligos simptomai labai i̇vairuoja - tai reiškia, kad kiekvienu atveju jie gali būti vis kitokie ir skirtingai pasireikšti esant tos pačios stadijos vėžiui. Kitų organų pažeidimo simptomatika paprastai išryškejja, kai plaučiu vėžys metastazuoja. Pasitaiko atvejų, kai liga visai nesukelia negalavimų, o aptinkama tik profilaktinio patikrinimo metu.

\section{PLAUČIŲ VĖŽIO DIAGNOSTIKOS ASPEKTAI}

Plaučių vèžio diagnostika remiasi klinikiniais simptomais, radiologiniais tyrimais, vertinančiais tiek patị navikini darini, tiek galimą jo išplitimą (krūtinès ląstos rentgenograma, kompiuteriné tomografija ir (ar) magnetinio rezonanso tomografija, pozitronu emisijos tomografija su kompiuterine tomografija, pilvo organų echoskopija, kaulų scintigrafija); esama plaučių funkcija dažniausiai vertinama spirografijos tyrimu. Vis dèlto galutinai plaučiu vèžio diagnozè patvirtinama tik atlikus darinio histologinị tyrimą. Biopsija gali būti atliekama paprastos bronchoskopijos, rentgenu kontroliuojamos bronchoskopijos, endobronchinio ultragarsinio tyrimo metu ar atliekant chirurgines procedūras: vaizdo torakoskopiją, mediastinoskopiją. Kai yra išplitimo kepenyse, antinksčiuose ar 
pilvo ertmès limfmazgiuose požymių, nesant galimybès verifikuoti pagrindinị plaučiu darinị ar ịtariant, kad dariniai šių organų limfmazgiuose gali būti ir kitos histologinès kilmès, atliekamas endoskopinis ultragarsinis tyrimas. Jo metu galima paimti audinio gabalèlių histologiniam tyrimui (šio tyrimo metu techniškai galima paimti biopsiją iš kairiojo antinksčio, kairiosios kepenų skilties ar pilvo ertmès limfmazgių atliekant adatinę aspiracinę biopsiją). Jei darinys yra plaučiuc periferijoje, gali būti atliekama transtorakalinè plaučiuc audinio biopsija. Citologinis tyrimas (tiriant bronchų išplovas ir (ar) nuobrūžas; eksudacinio pleurito atveju - punktatą) informatyvesnis centrinio plaučių vẻžio atveju nei periferinio, tačiau diagnostine verte nusileidžia histologiniam tyrimui. Vien pagal citologinio tyrimo duomenis vėžys gali būti diagnozuotas tik gydytojų konsiliumo sprendimu, kai taikant visus galimus diagnostikos metodus nepavyksta nustatyti histologinès diagnozès ar šių metodų negalima taikyti dèl sunkios ligonio būklès [2]. Planuojant gydymą, molekulinei plaučių vẻžio diagnostikai vis dažniau atliekami molekulinių pažaidų tyrimai (nustatomos epidermio augimo veiksnio receptoriaus (angl. Epidermal growth factor receptor, EGFR) geno aktyvinančios mutacijos; anaplazinès limfomos receptoriaus tirozino kinazès (angl. Anaplastic lymphoma receptor tyrosine kinase, $A L K)$ geno translokacija). Išsiaiškinta, kad molekulinès pažaidos tiesiogiai susijusios su plaučių kancerogeneze, gali daryti įtaką klinikinei ligos eigai, lemti gydymo veiksmingumą. Pacientų atranka molekuliniams tyrimams priklauso nuo plaučių vėžio histologinio tipo ir atliktos procedūros [2]. Radikaliai pašalinus plaučių naviką operacijos metu, rekomenduojama tirti adenokarcinoma ar mišraus histologinio tipo naviku (turinčiu adenokarcinomos požymių; pvz., adenoskvamozine karcinoma) sergančius ligonius. Plokščiųjų ląstelių karcinoma, smulkiụjų ląstelių karcinoma, didelių ląstelių karcinoma sergančiu ligoniu tirti nerekomenduojama [2]. Kai, atlikus smulkiąsias biopsijas, negalima atmesti mišraus histologinio tipo, nustačius plokščiųjų ląstelių karcinomą, didelių ląstelių karcinomą, ne- smulkiųjų ląstelių plaučių karcinomą, neklasifikuojamą kitaip, ar smulkiųjų ląstelių karcinomą, rekomenduojama tirti ligonius dèl EGFR geno mutaciju ir ALK geno translokacijų, jei randama adenokarcinomai būdingų požymių (navikinès ląstelès gamina gleives ar teigiamai reaguoja su liaukiniam epiteliui būdingais imunohistocheminiais žymenimis) [2]. Nesant pakankamai tiriamosios medžiagos tiksliam histologiniam tipui nustatyti, dèl EGFR geno mutacijų ir ALK geno translokacijų konsiliumo sprendimu galima tirti ligonius, sergančius plokščiųjų ląstelių karcinoma, didelių ląstelių karcinoma, nesmulkiųjų ląstelių plaučių karcinoma, neklasifikuojama kitaip, ar smulkiųjų ląstelių karcinoma, kai negalima paneigti adenokarcinomos komponento ir yra klinikiniu predikciniu tirozino kinazių inhibitorių veiksmingumo veiksnių (jaunas amžius, nerūkę ar buvę lengvi rūkoriai - per metus surūkydavę mažiau nei 15 cigarečių pakelių) [2].

Be visų anksčiau aprašytų diagnostinių tyrimų, visada turi būti atliekami ir bendrieji kraujo tyrimai: vertinama galima anemija, trombocitu koncentracija, kepenų, inkstų rodikliai.

\section{PLAUČIŲ VĖŽIO GYDYMO PRINCIPAI}

Gydymas parenkamas atsižvelgiant ì naviko histologini tipą, ligos stadiją, gretutines ligas, funkcinę paciento būklę pagal ECOG (angl. Eastern Cooperative Oncology Group), molekulinius genetinius žymenis. Po atliktụ diagnostinių tyrimų plaučių véžys pradedamas gydyti nedelsiant. Rekomenduojama, kad smulkiụjų ląsteliụ plaučių véžio atveju nuo pirminès morfologinès diagnozès iki gydymo pradžios turi praeiti ne daugiau kaip 2 savaitès, nesmulkiųjų ląstelių plaučių véžio atveju - ne daugiau kaip 1 ménuo [2]. Gydymo taktika apsvarstoma daugiadisciplinio aptarimo metu, o gydymas taikomas tose gydymo istaigose, kuriose užtikrinamas reikiamas visų daugiadisciplinès komandos narių dalyvavimas, kompleksinis plaučių vẻžiu sergančių ligonių ištyrimas (įskaitant ir predikcinių bei prognozinių molekulinių genetinių žymenų nustatymo galimybę) bei gydymas (chirurginis, spindulinis gydymas, chemoterapija, galimos invazinès pulmonologinès procedūros) [2]. Plaučiuc vėžio gydymas priklauso ir nuo kardiopulmoninès sistemos funkcijos, ypač planuojant chirurginį ar radikalu spindulinị (chemospindulinị) gydymą, gretutinių ligų, kūno masės sumažèjimo bei kituc prognoziniuc veiksnių. Esant blogai ligonio funkcinei būklei (3 ar 4 balai pagal ECOG), sunkioms gretutinėms ligoms, ryškiam kūno masès sumažejjimui, blogiems plaučių funkcijos rodikliams, dažniausiai tenka apsiriboti geriausia palaikomąja priežiūra [2] Tačiau kai kuriais nesmulkiųjų ląsteliuc plaučių véžio atvejais galima taikyti taikinių terapiją ar smulkiųjų ląstelių plaučių véžio atvejais - chemoterapiją net esant blogai paciento funkcinei būklei.

Taikinių terapija - tai vienas naujausių ir sparčiai tobulèjančių pažengusio plaučių véžio gydymo metodų, kurio tikslas - kontroliuoti arba sustabdyti vèžinių ląstelių augimą. Biologiniai vaistai sąveikauja su pakitusiu baltymu, aptinkamu tik vẻžinèse ląstelèse, ir atrankiai ji blokuoja. Véžinè ląstelè dažniausiai ne nužudoma, o tik sustabdomas jos augimas ir dauginimasis [2]. Naujos kartos vaistai labai efektyvūs, tačiau tinka tik tiems ligoniams, kuriuc navike nustatomas vaisto taikinys.

\section{PLAUČIUU VÉŽIO PROFILAKTIKA, CHEMOPREVENCIJA}

Pagrindinis plaučiu vèžio profilaktikos tikslas - sumažinti mirštamumą nuo šios ligos. Metimas rūkyti - vienintelè pripažinta veiksminga plaučiu véžio profilaktikos priemonè. Kol kas nerasta kitų efektyvių būdų, padedančių sumažinti tikimybę susirgti šia liga ar jos išvengti [2]. Ne mažiau svarbu apsaugoti ir nuo nepageidaujamuc plaučių vẻžio gydymo sukeliamų reakcijų, stiprinti ligonio organizmą (ypač imunitetą tiek gydymo metu, tiek po jo), siekiant geresnio gydymo atsako ir geresnès gyvenimo kokybès. Pas gydytoją apsilankę ligoniai neretai užsimena, kad, be tradicinio jiems skiriamo plaučiuc vėžio gydymo, imunitetui ir organizmui stiprinti kliaujasi liaudies medicinos išmintimi, vartoja įvairiausius vaistinius preparatus. Tačiau dèl ¿̇vairių priežasčiu gydantysis gydytojas ne visada linkęs pritarti ar patarti. Be abejo, nèra ịrodymų, kad vaistingieji augalai, maisto papildai išgydytų ligą, bet gali pagerinti gyvenimo kokybę.

Véžio gydymas yra sudètingas, neretai lydimas nepageidaujamuc 
reiškinių, nes siekiant sunaikinti vėžio pažeistas ląsteles, nukenčia ir sveikosios. Nepageidaujamos reakcijos, be abejonès, priklauso ir nuo pasirinkto gydymo metodo, ir nuo intensyvumo, taip pat ir nuo ligonio bendrosios būklès. Dažnai po operacijos pacientai jaučia silpnumą, skausmą, po chemoterapijos ar jos metu gali tapti neatsparūs infekcijoms, dažni virškinimo trakto negalavimai: pykinimas, vėmimas, bendrieji reiškiniai: plaukụ slinkimas, apetito stoka ir pan. Spindulinis gydymas gali sukelti nuovargit, sutrikdyti apetitą, gali kilti vietiniu spinduliuojamos vietos odos reakcijų ir pan. Galimų nepageidaujamų kiekvieno gydymo reakcijų literatūroje aprašoma išties nemažai, skiriasi tik jų pasireiškimo dažnumas ar sunkumas. Situaciją sunkina bendras vėžinis intoksikacijos sindromas, kuri dažniau patiria išplitusia liga sergantys asmenys. Kadangi tradiciné medicina remiasi pripažintomis gydymo rekomendacijomis, dažniausiai orientuojamasi $\mathfrak{i}$ pagrindini gydymo taikini - plaučių vėží, o apie bendrą sveikatos stiprinimą neretai užmirštama arba tam skiriama per mažai dèmesio. Vis dèlto vienose naujausių plaučių véžio diagnostikos ir gydymo gairių kalbama ir apie integracinę onkologiją. Integracinę onkologiją galima apibūdinti kaip racionalų, įrodymais pagrịstą konvencinių gydymo metodų ir papildomų priemonių sujungimą $\mathfrak{i}$ vientisą individualią asmens gydymo sistemą, kuri apima ne tik paties vėžio, bet ir ligonio kūno, proto ir sielos gydymą [3]. Ikiklinikiniais ir klinikiniais tyrimais patvirtintas česnako, ciberžolès, žaliosios arbatos, amalo, kvercetino, bromelaino, dagio, kulkšnès, ašvagandos (Withania somnifera) ir vaistiniu grybų (ivvairiaspalvès kempès, reiši, šiitakès ir maitakès) antinavikinis ir imunomoduliacinis poveikis [3]. Galimos kelios vaistingųjų augalų skyrimo indikacijos [3]:

- Véžio ir metastazių profilaktika didelès rizikos ligoniams;

- Tradicinio gydymo nepageidaujamų reiškinių šalinimas;

- Adjuvantinè priemoné pagerinti chemopreparatu veiksmingumą ir saugumą;

- Imunomoduliacinè priemonè véžio atkryčiu profilaktikai po gydymo.

Piktybinių naviku chemoprevencija tai natūralių, sintetinių ar biologinių medžiagų vartojimas siekiant nuslopinti, sustabdyti ar pakeisti kance- rogenezès krypti. Chemoprevencija grindžiama koncepcija, teigiančia, kad piktybinis navikas atsiranda tam tikroje srityje, o karcinogenezès procesas yra laipsniškas. Keliama hipotezè, kad kancerogenezès biologinio proceso nutraukimas gali pakeisti kancerogenezès krypti ar ją nuslopinti [3].

Viena galimu chemoprevencijos priemonių plaučiuc véžio atveju yra Lidonium. Specialiosios medicininès paskirties maisto produktas buvo sukurtas kartu su Vilniaus universiteto Onkologijos instituto Fitoterapijos laboratorija. Lidonium vartojamas tik mitybos reguliavimui esant susilpnèjusiam ląsteliniam imunitetui, vėžio profilaktikos metu po specifinio gydymo, siekiant pagerinti onkologinių ligonių gyvenimo kokybę bei esant skrandžio, žarnyno, kepenų ir tulžies pūslès latakų, kvėpavimo takų spazmams, uždegimui. Lidonium sudètyje gausu ịvairių aktyviųjų medžiagų, kurios palankiai veikia daug organizmo funkcijų: virškinimą, imunitetą, nervų ir kvejpavimo sistemą, gleivinių ir odos būklę, šlapimo išsiskyrimo sistemą ir kt. Vienoje tabletèje yra vaistiniu medetkų (Calendula officinalis L.) žiedų sausojo ekstrakto, siauralapių gysločiuc (Plantago lanceolata L.) lapų sausojo ekstrakto, didžiųjų ugniažolių (Chelidonium majus L.) žolès sausojo ekstrakto, glutationo, L-metionino, L-cisteino ir seleno (100 proc. rekomenduojamos paros normos).

Didžiųjų ugniažolių žolès sausajame ekstrakte yra alkaloidų: chelidonino, berberino, sangvinarino, chelitrino, chelidono, organinių rūgščių, karotinoidų, flavonoidų. Nustatyta, kad ugniažolèje esančios veikliosios medžiagos skatina tulžies išsiskyrimą, turi spazmolitinị poveikị, panašu i papaverino, todèl, mažindamos virškinimo organų lygiụjų raumenų spazmus, gali padèti malšinti skausmą ir raminti. Alkaloidas berberinas skatina tulžies sekreciją. Sangvinarinas, didindamas acetilcholino kiekị, padeda gerinti impulso plitimą nervų ir raumenų jungtyse. Chelitrinas slopina CNS veiklą, todèl didžiųjų ugniažolių žolè gali būti vartojama kaip pagalbinè priemonè tulžies pūslès ir takų funkcijai palaikyti, tulžies išsiskyrimui gerinti, jei negalavimu priežastis - sutrikusi nervinè reguliacija. Perdozavimas gali pasireikšti pykinimu, vėmimu, kvėpavimo centro slopinimu.

Vaistinių medetkų žiedų sausajame ekstrakte yra eterinių aliejų, mentono, gama terpineno, flavonoidų, kverceti- no darinių, saponinų, kalenduliozidų, karotinoidų, polisacharidų ir kt. Šioms medžiagoms būdingos uždegimą slopinančios savybès, todèl jos gali padèti spartinti granuliacijų susidarymą ir žaizdų gijimą, mažinti skausmą. Turi imunomoduliacinių, antioksidacinių, antivirusinių, antibakterinių, antinavikiniu savybių. Padeda gerinti miegą dèl raminamojo poveikio CNS.

Siauralapių gysločių lapų sausajame ekstrakte yra glikozidų: aukubino, polisacharidų, taninų, flavonoidų, cinko, kalio, gleivių, raugų, kartumynų, organinių rūgščių. Siauralapių gysločių lapu ekstrakto veikliosios medžiagos veikia spazmolitiškai, padeda gerinti atsikosejjimą, mažinti pabrinkimus, gyti žaizdoms ir opoms, gerinti epitelizaciją, varyti tulži ir šlapimą, mažinti žarnyno uždegimą, turi antinavikinių, imunostimuliuojamųjų ir koaguliacinių savybių.

Lidonium sudètyje esančios aminorūgštys ir gliutationas, trijų aminorūgščių junginys, pasižymi antioksidaciniu poveikiu. Gliutationas laikomas visų antioksidantų motina jis ne tik pats padeda apsaugoti ląsteles nuo oksidacinio streso, bet ir regeneruoti kitus savo funkciją atlikusius antioksidantus. Tam tikru gliutationo formu santykis organizme rodo organizmo oksidacinę redukcinę būklę, nuo kurios priklauso oksidacinio streso rizika.

Šios sudètinès dalys pasižymi imunomoduliaciniu, detoksikuojamuoju, antinavikiniu poveikiu, padeda apsaugoti organizmą nuo apšvitos, šalinti sunkiuosius metalus iš organizmo, būtinos baltymų sintezei. L-metioninas vartojamas esant kepenu problemoms padeda apsaugoti nuo riebaluc kaupimosi kepenyse, palaikyti normalią lecitino gamybą, turi antidepresiniu savybiuc, todèl padeda palaikyti gerą nuotaiką, mažinti lètinio nuovargio simptomus. Rekomenduojamas 6 ciklų Lidonium kursas. Norint užtikrinti saugu preparato vartojimą, kas $2-3$ ménesius reikia atlikti biocheminius ALT, AST, GGT, ŠF tyrimus.

\section{LITERATŪRA}

1. Vèžio tyrimy organizacijos (angl. Cancer Research UK) ataskaitos internetinè prieiga http://publications.cancerresearchuk.org/downloads/Product/ CS KF LUNG.pdf

2. Žemaitis $M$ ir kt. Plaučių vėžio diagnostikos ir gydymo rekomendacijos. 2013:6.

3. Danila E ir kt. Plaučiu vèžio diagnostikos ir gydymo gairès. Metodinès rekomendacijos. 2013:192-195. 